Bull. Egypt. Soc. Physiol. Sci. 36 (2), 53-67

\author{
Bull. of Egyp. Soc. Physiol. Sci. \\ (Official Journal of Egyptian Society for Physiological Sciences) \\ (pISSN: 1110-0842; eISSN: 2356-9514)
}

\title{
Xenobiotics Metabolizing Enzymes Gene Polymorphism and susceptibility of Hepatocellular Carcinoma in Egyptian Patients with Hepatitis C Virus-induced Cirrhosis
}

\author{
Manar Obada ${ }^{1}$, Ashraf El-Fert ${ }^{1}$, Asmaa Gomaa ${ }^{2}$, Mohamed Hashim², Mohamed Kohla²,Wael Abdelrazek², \\ Om kolsoum El hadad ${ }^{2}$, Hala El-Said ${ }^{1}$
}

Clinical Biochemistry ${ }^{1}$, Hepatology ${ }^{2}$ Departments, National Liver Institute, Menoufia University

Received: 10 Aug,2016

Accepted: 26,Sept ,2016

Available online: 25 Dec 2016

Keywords

- Polymorphism

- Xenobiotics

- metabolizing

enzymes

- genes

- hepatocellular

carcinoma

\begin{abstract}
Background: Chronic hepatitis $\mathrm{C}$ virus (HCV) infection is the most frequent cause of progressive liver disease and hepatocellular carcinoma (HCC) in Egypt. Risk of HCC can be affected by the exposure to endogenous or environmental toxins. Genetic polymorphism of the carcinogensmetabolizing enzymes, were suggested as modifiers of cancer risk. So, the present study aimed to investigate the association between xenobiotic metabolizing enzymes [cytochrome P450 (CYP2D6), N-acetyl transferase 2 (NAT2) and UDP-glucuronosyltransferase 1A7 (UGT1A7)] gene polymorphism and the risk of $\mathrm{HCC}$ in patients with chronic HCV-induced cirrhosis compared to normal and chronic HCV infected subjects. Subjects and Methods: 354 subjects, divided into 3 groups, (group I: 150 patients had chronic hepatitis C with HCC, group II: 104 patients had chronic hepatitis C without HCC and group III: 100 healthy controls. The studied genes were genotyped using polymerase chain reaction-restriction fragment length polymorphism and allelic discrimination assays. Results: CYP2D6*6 and CYP2D6*3 poor metabolizers (homozygous mutant genotypes) were significantly increased in HCC patients compared to controls and were associated with increased HCC risk with ORs and 95\%CI of 4.0 (2.5-6.4) and 3.32 (2.1-5.2) respectively. Meanwhile, CYP2D $6 * 4$ extensive metabolizer (homozygous wild genotypes; GG) was significantly increased in HCC patients compared to controls and was associated with increased HCC risk with ORs and 95\%CI of 2.3 (1.42-3.85). However homozygous mutant genotypes (slow acetylators) of NAT2 M1, M2 and M3 showed no significant difference between HCC patients and controls and were not associated with increased HCC risk. Also, genotypes of UGT1A7 gene showed no significant difference in HCC patients compared to other groups and had no effect on HCC susceptibility. Conclusion: Poor metabolizers' genotypes of CYP2D $6 * 6$ and CYP2D $6 * 3$ and extensive metabolizer genotypes of CYP2D 6*4 may be risk factors for HCC in patients infected with HCV. Meanwhile, NAT2 and UGT1A7 genes polymorphism were not associated with increased risk of HCC in the studied patients.
\end{abstract}

Corresponding author: Manar Obada, D Clinical Biochemistry Department, National Liver Institute, Menoufia University, Egypt.. Phone: +201154494477; email: manarobada@yahoo.com 


\section{Introduction}

Hepatocellular carcinoma (HCC) is the second leading cause of cancer-related death worldwide, and its incidence is increasing (1). In Egypt, due to the high prevalence of $\mathrm{HCV}$ and HBV infections, the incidence rate of HCC has doubled in the past ten years (2). A decrease in carcinogen metabolism and an increase in procarcinogen activation have also been documented as HCC risk factors (3).

Detoxification and elimination of drugs, environmentally relevant chemicals and endogenous metabolites is a major function of the liver and important in maintaining the metabolic homeostasis of the organism. Xenobiotics are metabolized by a large number of xenobiotic metabolizing enzymes which fall into three broad categories: phase I, phase II and phase III (4).

The major enzymes of phase I metabolism are heme thiolate proteins of the cytochrome P450 superfamily (CYPs). Phase I enzymes generate functional groups that may subsequently serve as a site for conjugation catalyzed by phase II enzymes UDP-glucuronosyltransferases

(UGT), Sulfotransferases (SULT), Glutathione S transferases (GST), and $\mathrm{N}$-acetyl transferases (NAT) (5) .

CYP2D6 is the most extensively studied polymorphically expressed drug metabolizing enzyme in humans. As a result of the presence of more than 70 allelic variants of CYP2D6 Gene (6), metabolism and excretion rates of drugs vary between individuals, from extremely slow to ultrafast (7).

$\mathrm{N}$-acetyl transferase-2 (NAT-2) is a polymorphic enzyme involved in the activation and deactivation of aromatic and heterocyclic amines. Polymorphisms of the NAT2 gene result in slow and rapid acetylators of potentially toxic substances (8).NAT2 is polymorphic, and the number of NAT2*4 functional alleles divides the population into rapid (two alleles), intermediate (one allele), and slow acetylators (none) (9)

Human UDP-glucuronosyltransferases (UGTs) can catalyze the conjugation of hydrophobic compounds of divergent chemical classes to form water soluble -D-glucopyranosiduronic acids. These metabolites then undergo renal or biliary elimination from the body (10).

The aim of this work was to investigate the association of the xenobiotic metabolizing enzymes (Cytochrome P450; CYP2D6, N-acetyl transferase 2 (NAT2) and UDPglucuronosyltransferase 1A7 (UGT1A7) genes polymorphism with the risk of $\mathrm{HCV}$ related $\mathrm{HCC}$ in Egyptian patients compared to $\mathrm{CHC}$ patients and normal subjects.

\section{Subjects and Methods}

This work was carried out in accordance with The Code of Ethics of the World Medical Association (WMA) Declaration of Helsinki (2008) for experiments in humans. The study was conducted at National Liver Institute, Menoufia University. 354 subjects were enrolled in this study and divided into 3 groups. Group I: 150 patients had chronic hepatitis C with HCC, Group II: 104 patients had chronic hepatitis $\mathrm{C}$ without HCC. Group III: 100 healthy controls (patients' age and gender matched) with normal liver and renal tests and negative for HBs antigen and HCV antibody. Diagnosis of HCC was based on non-invasive 
criteria using multi slice triphasic CT or contrast enhanced dynamic MRI. The presence of typical features of arterial enhancement and rapid portal or delayed washout on one imaging technique was diagnostic of $\mathrm{HCC}$ for nodules $>2 \mathrm{~cm}$ in diameter in cirrhotic patients. In cases of uncertainty or atypical radiological findings, diagnosis was confirmed by a biopsy (11). Diagnosis of CHC infection was based on the presence of positive anti-HCV antibody and/or HCV RNA. Diagnosis of liver cirrhosis was based on ultrasonographical findings (shrunken liver, coarse echo pattern, attenuated hepatic vein and nodular surface) and biochemical evidence of parenchymal damage (12). Written informed consents were taken from all participants and the study protocol was approved by the Institution's ethics committee.

\section{Laboratory Investigations}

Basic laboratory investigations were done for all participants; liver tests, $\mathrm{CBC}$, serum $\mathrm{HBs} \mathrm{Ag}$ and Anti-HCV antibodies and serum AFP using fully automated auto-analyzer SYNCHRON CX9ALX (Beckman Coulter Inc., CA, USA), Sysmex K-21, (Sysmex Corporation, Kobe, Japan), immunoassay (Abbott Laboratories, Abbott Park, IL, USA), and Automated IMMULITE® 1000 immunoassay analyzer (Siemens Medical Solutions Diagnostics Corporation, Erlangen, Germany) respectively.

\section{Genotyping}

Genomic DNA was extracted from EDTA-treated whole blood using Gene JET Whole Blood Genomic DNA Purification Mini Kit, (Thermo Fisher Scientific, MA USA). All primers used in this study were synthesized at Metabion international AG, Martinsried, Germany.

\section{NAT 2}

Genotyping of NAT2*5(Ml allele) (C481T) rs1799929, NAT2*6 (M2 allele) (G590A) rs1799930, and NAT2*7 (M3 allele) (G857A) rs1799931 was carried out as described by Bell et al., (13), with modification. NAT2 genotyping was performed by polymerase chain reaction and restriction fragment length polymorphism assay (PCR-RFLP). PCR was carried out using PCR primers (N5, 5'-GGAACAAATTGGACTTGG-3'; N4, 5'-TCTAGCATGAATCACTCTGC-3') Dream Taq Green PCR Master Mix (Thermo Fisher Scientific, MA, USA) was utilized in the amplification. The cycling conditions consist of $94^{\circ} \mathrm{C}$ for $3 \mathrm{~min}$, followed by 35 cycles of $94^{\circ} \mathrm{C}$ for $30 \mathrm{~s}, 52^{\circ} \mathrm{C}$ for $40 \mathrm{~s}$ and $72^{\circ} \mathrm{C}$ for $90 \mathrm{~s}$, with a final extension of $72^{\circ} \mathrm{C}$ for $5 \mathrm{~min}$. Following PCR, the amplicon was subjected to restriction digest with Kpnl (Ml allele), TaqI (M2 allele), BamHI (M3 allele) restriction enzymes from (Thermo Fisher Scientific, MA, USA). The restriction digests were electrophoresed on $3.5 \%$ agarose gels (fig 1).

\section{UGT1A7}

\section{a. UGT1A7 [codon 208 (nucleotide T622C) rs11692021]}

Genotyping of UGT1A7 (W208R) was carried out as described by Tseng et al. (14) by PCR-RFLP. The primers U7F3 5' TGTCCCCAGACTTCTCTTAG-3' and U7R3 5'GCTACCCAACAATTAAGTGA-3' were used to amplify the specific UGT1A7 fragments that cover nucleotide 622. For the amplification, Dream Taq Green PCR Master Mix (Thermo Fisher Scientific, MA, USA) was utilized. The cycling conditions consist of $94^{\circ} \mathrm{C}$ for $3 \mathrm{~min}$, followed by 35 cycles 
of $94^{\circ} \mathrm{C}$ for $30 \mathrm{~s}, 52^{\circ} \mathrm{C}$ for $30 \mathrm{~s}$ an and $72^{\circ} \mathrm{C}$ for 60

$\mathrm{s}$, with a final extension of $72^{\circ} \mathrm{C}$ for $5 \mathrm{~min}$. This PCR yielded a 447bp fragment, which was digested with restriction enzyme RsaI (Thermo

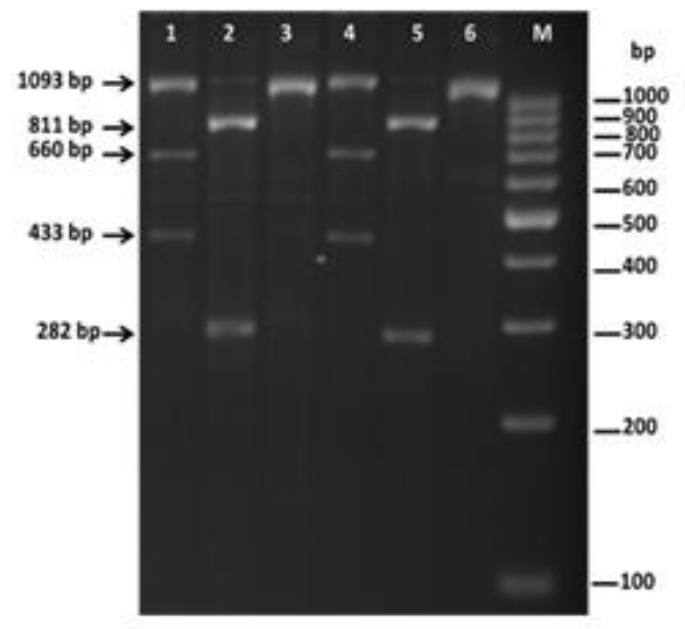

A
Fisher Scientific, MA, USA). The restriction digests were electrophoresed on $2 \%$ agarose gels (figure 2).

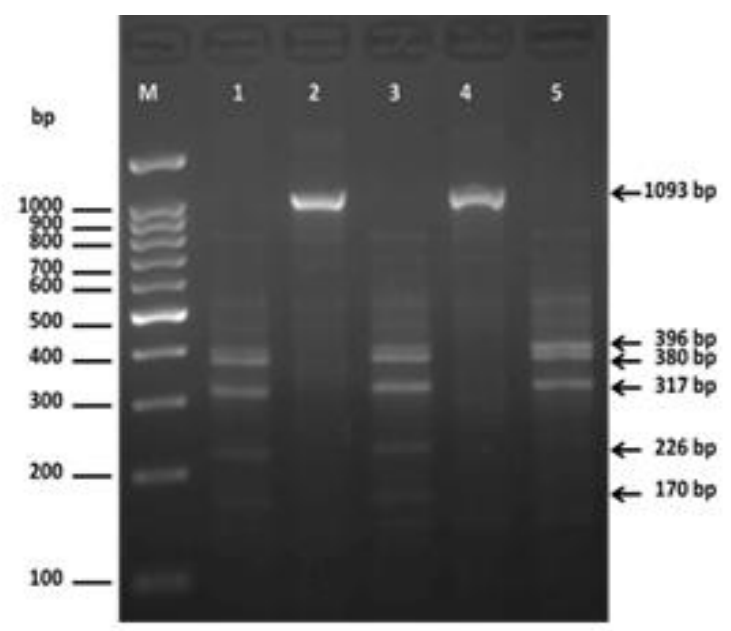

B

Fig (1) Representative examples of different NAT2* genotypes:

A. NAT2*5 (Ml allele C481T) and NAT2*7 (M3 alleleG857A) M1 (C) wild type(rapid acetylator) shows two bands of 660 and 433bp, whereas (T) mutant type(slow acetylator)yields a single band of 1093bp. M3 (G) wild type (rapid acetylator) generates two bands of 811 and 282bp, whereas (A) mutant type(slow acetylator) yields a single band of 1093bp. M1 allele in lanes 1 (CT), 4 (CT) and 6 (TT) genotypes.M3 allele in lanes $2(\mathrm{GG}), 3(\mathrm{AA})$ and $5(\mathrm{GG})$ genotypes.

B. NAT2*6 (M2) allele G590A: M2 (G) wild type (rapid acetylator) generates bands 380, 317, 226, and 170bp bands 660 and 433bp, whereas (A) mutant type(slow acetylator) yields 396, 380, and 317bp bands. Lanes 2 and 4 showed undigested samples of 1093bp, lanes 1 and 3 showed GA genotype while lane 5 showed AA genotype.

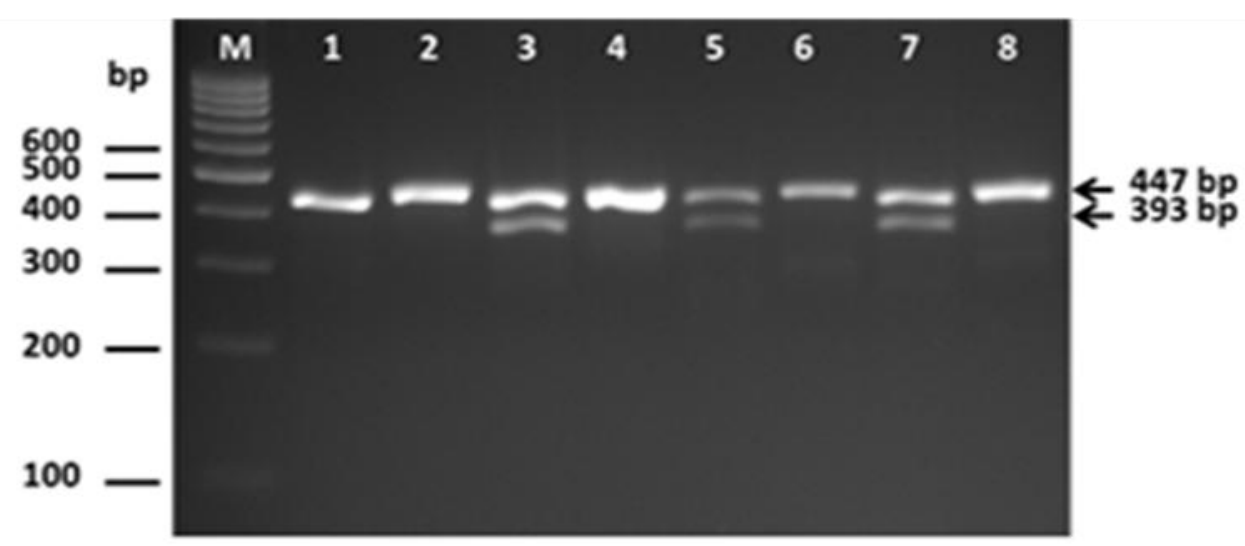

Fig (2) Representative examples of UGT1A7 [codon 208 (nucleotide T622C) rs11692021]UGT (T) wild type yielded a single band of 447bp, whereas the (C) mutant type generates two bands of 393 and 54bp. Lanes 1,2,4,6, and 8 showed the TT genotype, while lanes 3, 5 and 7 showed TC genotype. The samples were electrophoresed against100bp DNA ladder (M) (100bp Gene ruler DNA Ladder, Thermo Scientific Inc., USA. The land mark band of the ladder is corresponds to 500bp).

b. UGT1A7 [codon 129 (nucleotide T387G) rs17868323]

The single nucleotide polymorphism of UGT1A7 $(\mathrm{N} 129 \mathrm{~K})$ was detected by using TaqMan allelic 
discrimination Assay. Primers and probes used were: N129K-Forward: 5'CACCATTGCGAAGTGCATTT-3'; N129KReverse 5'-GGATCGAGAAACACTGCATCAA3'; Probe 5AM-N129 5'CAGGaGTTTGTTTAATGAC-3'; Probe VICK129 5'-CAGGAGTTTGTTTAAGGAC-3'.

The presence of two primer/probe pairs in each reaction allows genotyping of the two possible variants at the single-nucleic polymorphism site in a target template sequence. This allows the classification of unknown samples as: homozygote (samples having only allele 1 or allele 2 ) or heterozygote (samples having both allele 1 and allele 2). The genotyping reaction mix was prepared using Maxima Probe qPCR Master Mix (Thermo Fisher Scientific, MA, USA). The cycling conditions consisted of initial denaturation step at 940C for 4 minutes, followed by 50 cycles of denaturation at $940 \mathrm{C}$ for 30 seconds, annealing/extension /fluorescence acquisition at 600C for 30 seconds; Using LINE GENE 9660 (BIOER Technology, Hangzhou, China).

\section{Cytochrome P450 (CYP2D6) Gene Polymorphisms}

The allelic discrimination of the CYP2D6*3, CYP2D6*4, CYP2D6*6 polymorphisms were assessed with the ABI 7500F Real-Time PCR Instrument (Applied Biosystems, Inc. (ABI) Foster City, CA) using TaqMan assay. The TaqMan Assay-on-Demand reagents available for CYP2D6*3 25491Adel where deletion of base A (rs35742686) [assay ID C-32407232-50], CYP2D6*4 G1846A (rs3892097) [assay ID C27102431-D0], CYP2D6*6 1707Tdel where deletion of base T occurs (rs5030655) [assay ID C-
32407243-20]. TaqMan Universal PCR Master Mix was used for analysis. The PCR profile consisted of an initial denaturation step at $95^{\circ} \mathrm{C}$ for 10 minutes and 40 cycles of $92^{\circ} \mathrm{C}$ for 15 seconds and $60^{\circ} \mathrm{C}$ for 1 minute and fluorescence acquisition.

\section{Statistical analysis}

Data were statistically described in terms of range; mean \pm standard deviation (SD), frequencies (number of cases) and relative frequencies (percentages) when appropriate. SPSS Version 17.0 (SPSS Inc., Chicago, IL, United States) was used for all data analyses. Chi-square or Fisher exact tests were used for contrasts involving categorical variables. For comparisons involving continuous variables, the two sided Student $t$ test or Welch Modified ANOVA were used. A probability value ( $\mathrm{p}$ value) less than 0.05 was considered statistically significant. The genotype frequencies of the studied genes were compared with predictable values calculated from Hardy-Weinberg equilibrium (p2+ $2 p q+q 2=1$; where $p$ is the frequency of the wildtype allele and $q$ is the frequency of the variant allele.

\section{Results}

The mean age for HCC patients was $53.7 \pm 7.80$ years and $80 \%$ were males, for $\mathrm{CHC}$ patients; it was $45.01 \pm 5.5$ years and $78.80 \%$ were males and for healthy subjects it was $43.2 \pm 4.6$ years and $77 \%$ were male.

Demographic data of the HCC group were shown in Table 1, where the mean tumor diameter was 4.9 $\pm 2.8 \mathrm{~cm}$, the median TTV was $33.49 \mathrm{~cm}$, the mean AFP was $217.2 \mathrm{ng} / \mathrm{mL}$. $44.7 \%$ of the patients had ascites. Lymph node invasion was present in 5\% and vascular invasion was present in $10.6 \%$ of $\mathrm{HCC}$ 
patients.14.6\% of HCC patients were Child-Pugh C and $14 \%$ were BCLC stage D.

Comparison of frequencies of the studied genotypes among HCC patients, CHC patients and healthy subjects is displayed in table (2), as shown in the table there was a significant difference between the studied groups regarding the frequencies of NAT2 M1 CC genotype (rapid acetylator) which showed significant decrease in HCC patients compared to CHC patients, also, NAT2M1 CT genotype showed significant decrease in $\mathrm{CHC}$ patients compared to healthy subjects.

Regarding NAT2 M3, GG genotypes (rapid acetylator) showed significant decrease in HCC patients compared to the other two groups. No significant difference was detected between $\mathrm{CHC}$ patients and healthy subjects.

Regarding NAT2 M2 genotypes; no significant difference was noticed between the studied groups.

Regarding CYP2D 6*6; Wt/Wt genotype (extensive metabolizer) showed significant decrease in HCC patients and in $\mathrm{CHC}$ patients compared to healthy subjects. Wt/Mut genotype (intermediate metabolizer) was significantly decreased in $\mathrm{HCC}$ patients compared to $\mathrm{CHC}$ patients. Meanwhile, Mut/Mut genotype (poor metabolized) showed significant elevation in HCC patients compared to the other studied groups; also it was significantly elevated in $\mathrm{CHC}$ patients compared to healthy subjects.

\section{Regarding CYP2D 6*4; GG (extensive} metabolizer) was significantly elevated in $\mathrm{HCC}$ patients compared to healthy subjects. While, GA genotype (intermediate metabolizer) showed significant decrease in HCC patients compared to healthy subjects. No significant difference was detected between $\mathrm{CHC}$ patients and healthy subjects

Regarding CYP2D6*3; Wt/Wt genotype (extensive metabolizer) showed significant decrease in HCC patients compared to healthy subjects. Also, Wt/Mut (intermediate metabolizer) showed significant decrease in HCC patients compared to other two groups. Meanwhile, Mut/Mut genotype (poor metabolizer) was significantly elevated in HCC patients compared to the other two groups. No significant difference was detected between $\mathrm{CHC}$ patients and healthy subjects.

Regarding UGT1A7 gene, no significant difference was observed regarding genotypes of UGT1A7 gene between the studied groups. No significant difference between various genotypes of the studied genes regarding pathological criteria and basic laboratory parameters of HCC patients (data not shown).

Table (3) presented comparison between group I (HCC patients) and non-HCC controls (group II and III) regarding frequency of NAT2 alleles and genotypes and associated HCC risk; where mutant alleles of NAT2 M2 and M3 (A allele; slow acetylators) showed significant increase in HCC patients compared to controls ( $\mathrm{CHC}$ patients and healthy subjects) with increased risk of HCC development, where ORs were 1.67 and 1.99 respectively, however homozygous mutant genotypes (slow acetylators) of NAT2 M1, M2 and M3 ( TT vs. $\mathrm{CT}+\mathrm{CC}, \mathrm{AA}$ vs.GA $+\mathrm{GG}$ and $\mathrm{AA}$ vs. $\mathrm{GA}+\mathrm{GG}$ respectively; recessive model) showed no significant difference between HCC patients and controls with no association with increased HCC risk. Meanwhile, 
NAT2 homozygous wild genotypes of M1 (CC vs. $\mathrm{CT}+\mathrm{TT}$ ), M2 (GG vs. GA + AA) and M3 (GG vs. GA + AA) (dominant models) showed significant decreased risk of HCC with OR and 95\%CI of 0.6 $(0.36-0.99), 0.54(0.35-0.83)$ and $0.46(0.28-0.74)$ respectively.

Table (4) displayed Comparison between group I (HCC patients) and non-HCC controls (group II and III) regarding frequency of CYP2D6* alleles and genotypes and associated HCC risk; as shown CYP2D6*6 and CYP2D6*3 mutant alleles (Mut vs. $\mathrm{Wt}$ ) and mutant genotypes; poor metabolizers (Mut/Mut vs, Wt/Wt+ Wt/Mut; recessive model) were significantly increased in HCC patients compared to controls and were associated with increased $\mathrm{HCC}$ risk with ORs and 95\%CI of 2.9 (2.09-4.1) and 2.73 (1.9 3.9) respectively for mutant alleles and 4.0 (2.5 6.4) and 3.32 (2.1-5.2) respectively for poor metabolizers, meanwhile, wild genotypes; extensive metabolize (Wt/Wt vs. Wt/Mut+Mut/Mut; dominant model) showed significant decrease in HCC patients compared to controls and were associated with decreased risk of HCC with OR and 95\%CI of0.037 (0.002-0.2) and $0.15(0.036-0.47)$ respectively . For CYP2D6*4; wild genotype (GG; extensive metabolizer) showed significant increase in $\mathrm{HCC}$ patients compared to controls and was associated with increased risk of HCC with OR of 2.3 and 95\%CI was1.42-3.85, while $\mathrm{A}$; mutant allele and poor metabolizer genotype; AA (AA vs. GA+GG, recessive model) showed significant decrease in $\mathrm{HCC}$ patients compared to controls and were associated with decreased HCC risk with ORs and 95\%CI of 0.55 (0.37-0.8) and $0.16(0.09-0.29)$ respectively.
Also, multivariate logistic regression analysis showed that only, mutant homozygous genotypes of CYP2D6*6 and CYP2D6*3 and wild homozygous genotype of CYP2D6*4 were predictors of $\mathrm{HCC}$ (Table 5).

\section{DISCUSSION}

HCC is often accompanied by severe liver dysfunction that is closely related to disease progression, which can influence $\mathrm{HCC}$ treatment decisions. HCC pathogenesis involves multiple factors and is often promoted by chronic infection with the hepatitis virus, especially hepatitis B and C virus (HBV and $\mathrm{HCV}$ ) (15). One of the many risk factors of HCC is the patient's capability to metabolize xenobiotics, because some xenobiotics play a role in inducing cancer as procarcinogen or carcinogen (16).

$\mathrm{N}$-acetyltransferase (NAT2) is involved in the metabolic activation and detoxification of aromatic amines, which are potential hepatocarcinogens in humans. Genetic polymorphism is associated with slow acetylation which predisposes to HCC development because of decreased deactivation of aromatic amines (17).

The current study showed that slow acetylators of NAT2 gene (M1 TT, M2 AA and M3 AA genotypes) showed no significant difference between HCC patients and both control groups (CHC patients and healthy subjects). Moreover, there was no statistically significant association between these genotypes and risk of HCC (slow acetylators vs. intermediate and rapid acetylators, recessive model) although there were increased frequencies of NAT2 M2 and M3 mutant alleles (A allele, slow acetylators) in HCC compared to other 
Table (1) Demographic data of HCC patients $(\mathrm{No}=150)$

\begin{tabular}{|c|c|}
\hline Variables & Values \\
\hline Tumor diameter $(\mathrm{cm})$, mean \pm SD & $4.9 \pm 2.8$ \\
\hline TTV (cm3), median (IQR) & $33.49(0.52-8177.1)$ \\
\hline $\operatorname{AFP}(\mathrm{ng} / \mathrm{ml})$, mean \pm SD & $217.2 \pm 105.5$ \\
\hline $\begin{array}{c}\text { Ascites, } \mathbf{n}(\%) \\
\text { absent/ Moderate/Tense }\end{array}$ & 83 (55.3), 50 (33.3), 17 (11.3) \\
\hline Lymph node invasion, $\mathrm{n}(\%)$ & $8(5.0)$ \\
\hline Vascular invasion, $\mathrm{n}(\%)$ & $16(10.6)$ \\
\hline $\begin{array}{c}\text { Patients' Child Pugh Class, n (\%) } \\
\text { A/B/C }\end{array}$ & $72(48.0) / 56(37.3) / 22(14.6)$ \\
\hline Patients' BCLC stage, n (\%) A/B/C/D & $90(60.0) / 20(13.3) / 19(12.6) / 21(14.0)$ \\
\hline $\begin{array}{l}\text { Number of patients with: } \\
\text { Solitary/ } 2 \text { nodules/ } \geq 3 \text { nodules }[\mathrm{n}(\%)]\end{array}$ & $116(77.4) / 32(21.3) / 2(1.3)$ \\
\hline $\begin{array}{l}\text { Number of Patients with affected lobe(s): } \\
\text { Right lobe/ Left lobe/ Both lobes [n }(\%)]\end{array}$ & $94(62.7) / 30(20.0) / 26(17.3)$ \\
\hline
\end{tabular}

TTV:total tumor volume, AFP: alpha fetoprotein, BCLC: Barcelona Clinic Liver Cancer, IQR: interquartile range, SD: standard deviation.

Table (2) Comparison of polymorphic patterns of the studied genes among the studied groups

\begin{tabular}{|c|c|c|c|c|c|}
\hline Genotypes & & $\begin{array}{l}\text { Group I } \\
\mathbf{n}=150(\%)\end{array}$ & $\begin{array}{c}\text { Group II } \\
n=104(\%)\end{array}$ & $\begin{array}{l}\text { Group III } \\
\mathbf{n}=100(\%)\end{array}$ & $\mathbf{P}$ \\
\hline \multirow[t]{3}{*}{ NAT2*5(M1) } & $\mathrm{CC}$ & $29(19.3)^{\mathbf{a}}$ & $34(32.7)$ & $24(24.0)$ & \multirow[t]{3}{*}{$0.036^{*}$} \\
\hline & TT & $38(25.3)$ & $27(26.0)$ & $17(17.0)$ & \\
\hline & CT & $83(55.3)$ & $43(41.3)^{b}$ & $59(59.0)$ & \\
\hline \multirow[t]{3}{*}{ NAT2*6 (M2) } & GG & $63(42.0)$ & $60(57.7)$ & $57(57.0)$ & \multirow[t]{3}{*}{0.052} \\
\hline & AA & $24(16.0)$ & $11(10.6)$ & $8(8.0)$ & \\
\hline & GA & $63(42.0)$ & $33(31.7)$ & $35(35.0)$ & \\
\hline \multirow[t]{3}{*}{ NAT2*7(M3) } & GG & $96(64.0)^{\mathbf{a b}}$ & $82(78.8)$ & $80(80.0)$ & \multirow[t]{3}{*}{$0.032 *$} \\
\hline & AA & $9(6.0)$ & $3(2.9)$ & $3(3.0)$ & \\
\hline & GA & $45(30.0)$ & $19(18.3)$ & $17(17.0)$ & \\
\hline \multirow{3}{*}{$\begin{array}{l}\begin{array}{l}\text { UGT1A7 } \\
\text { (codon208) }\end{array} \\
\end{array}$} & TT & $42(28.0)$ & $37(35.6)$ & $35(35.0)$ & \multirow[t]{3}{*}{0.713} \\
\hline & $\mathrm{CC}$ & $23(15.3)$ & $14(13.5)$ & $14(14.0)$ & \\
\hline & $\mathrm{TC}$ & $85(56.7)$ & $53(51.0)$ & $51(51.0)$ & \\
\hline \multirow{3}{*}{$\begin{array}{l}\begin{array}{l}\text { UGT1A7 } \\
(\text { codon129) }\end{array} \\
\end{array}$} & TT & $44(29.3)$ & $18(17.3)$ & $21(21.0)$ & \multirow[t]{3}{*}{0.054} \\
\hline & GG & $55(36.7)$ & $33(31.7)$ & $39(39.0)$ & \\
\hline & TG & $51(34.0)$ & $53(51.0)$ & $40(40.0)$ & \\
\hline \multirow[t]{3}{*}{ CYP2D6*6 } & $\mathrm{Wt} / \mathrm{Wt}$ & $1(0.7)^{b}$ & $4(3.8)^{b}$ & $27(27.0)$ & \multirow{3}{*}{$<0.001 *$} \\
\hline & Mut/Mut & $84(56.0)^{\mathbf{a b}}$ & $33(31.7)^{\mathbf{b}}$ & $16(16.0)$ & \\
\hline & Wt/Mut & $65(43.3)^{\mathbf{a}}$ & $67(64.4)$ & $57(57.0)$ & \\
\hline \multirow[t]{3}{*}{ CYP2D6*4 } & GG & $121(80.7)^{b}$ & $74(71.2)$ & $57(57.0)$ & \multirow[t]{3}{*}{$<0.001^{*}$} \\
\hline & AA & 17 (11.3) & $17(16.3)$ & $11(11.0)$ & \\
\hline & GA & $12(8.0)^{b}$ & $13(12.5)$ & $32(32.0)$ & \\
\hline \multirow[t]{3}{*}{ CYP2D6*3 } & $\mathrm{Wt} / \mathrm{Wt}$ & $3(2.0)^{b}$ & $7(6.7)$ & $17(17.0)$ & \multirow{3}{*}{$<0.001 *$} \\
\hline & Mut/Mut & $99(66.0)^{\mathbf{a b}}$ & $41(39.4)$ & $34(34.0)$ & \\
\hline & Wt/Mut & $48(32.0)^{\mathbf{a b}}$ & $56(53.8)$ & $49(49.0)$ & \\
\hline
\end{tabular}

Data are no $(\%)$. ${ }^{\mathrm{a}} \mathrm{P}<0.05$ compared to group II, ${ }^{\mathrm{b}} \mathrm{P}<0.05$ compared to group III, ${ }^{*} \mathrm{p}<0.05$ : significant, $\mathrm{p}>0.05$ : nonsignificant 
Table (3) Comparison between group I (HCC patients) and non-HCC controls (group II \& III) regarding frequency of NAT2 alleles and genotypes and associated HCC risk,

\begin{tabular}{|c|c|c|c|c|}
\hline Frequency & $\begin{array}{l}\text { Group I } \\
(\text { no=150) } \\
\text { No }(\%)\end{array}$ & $\begin{array}{l}\begin{array}{c}\text { Controls } \\
(\text { no= }=204)\end{array} \\
\text { No }(\%)\end{array}$ & $\begin{array}{l}\text { p- } \\
\text { value }\end{array}$ & $\begin{array}{l}\text { OR } \\
(95 \% \mathrm{CI})\end{array}$ \\
\hline $\begin{array}{l}\text { NAT2*5 M1 } \\
\text { T Mut allele } \\
\text { C Wt allele }\end{array}$ & $\begin{array}{l}159(53.0) \\
141(47.0)\end{array}$ & $\begin{array}{l}190(46.6) \\
218(53.4)\end{array}$ & 0.09 & $\begin{array}{c}1.29 \\
(0.95-1.74)\end{array}$ \\
\hline $\begin{array}{c}\text { NAT2*5 M1 } \\
\text { Dominant } \\
\text { model } \\
\text { CC } \\
\text { CT + TT }\end{array}$ & $\begin{array}{l}29(19.3) \\
121(80.7)\end{array}$ & $\begin{array}{c}58(28.4) \\
146(71.6)\end{array}$ & $0.024 *$ & $\begin{array}{c}0.6 \\
(0.36-0.99)\end{array}$ \\
\hline $\begin{array}{c}\text { NAT2*5 M1 } \\
\text { Recessive } \\
\text { model } \\
\text { TT } \\
\text { CT + CC }\end{array}$ & $\begin{array}{l}38(25.3) \\
11(74.7)\end{array}$ & $\begin{array}{c}44(21.6) \\
160(78.4)\end{array}$ & 0.21 & $\begin{array}{c}1.23 \\
(0.74-2.03)\end{array}$ \\
\hline $\begin{array}{l}\text { NAT2*6 M2 } \\
\text { A Mut allele } \\
\text { G Wt allele }\end{array}$ & $\begin{array}{l}111(37.0) \\
189(63.0)\end{array}$ & $\begin{array}{l}106(26.0) \\
302(74.0)\end{array}$ & $0.008 *$ & $\begin{array}{c}1.67 \\
(1.21-2.3)\end{array}$ \\
\hline $\begin{array}{c}\text { NAT2 } * 6 \text { M2 } \\
\text { Dominant } \\
\text { model } \\
\text { GG } \\
\text { GA + AA }\end{array}$ & $\begin{array}{l}63(42.0) \\
87(58.0)\end{array}$ & $\begin{array}{c}117(57.4) \\
87(42.6)\end{array}$ & $0.002 *$ & $\begin{array}{c}0.54 \\
(0.35-0.83)\end{array}$ \\
\hline $\begin{array}{c}\text { NAT2 } * 6 \text { M2 } \\
\text { Recessive } \\
\text { model } \\
\text { AA } \\
\text { GA + GG }\end{array}$ & $\begin{array}{c}24(16.0) \\
126(84.0)\end{array}$ & $\begin{array}{c}19(9.3) \\
185(90.7)\end{array}$ & 0.06 & $\begin{array}{c}1.85 \\
(0.97-3.56)\end{array}$ \\
\hline $\begin{array}{c}\text { NAT2*7 } \\
\text { M3 } \\
\text { A Mut allele } \\
\text { G Wt allele }\end{array}$ & $\begin{array}{c}63(21.0) \\
237(79.0)\end{array}$ & $\begin{array}{c}48(11.8) \\
360(88.2)\end{array}$ & $0.004 *$ & $\begin{array}{c}1.99 \\
(1.32-3.01)\end{array}$ \\
\hline $\begin{array}{c}\text { NAT2*7 M3 } \\
\text { Dominant } \\
\text { model } \\
\text { GG } \\
\text { GA+AA }\end{array}$ & $\begin{array}{l}96(64.0) \\
54(36.0)\end{array}$ & $\begin{array}{c}162(79.4) \\
42(20.6)\end{array}$ & $0.007^{*}$ & $\begin{array}{c}0.46 \\
(0.28-0.74)\end{array}$ \\
\hline $\begin{array}{c}\text { NAT2*7 } \\
\text { M3 } \\
\text { Recessive } \\
\text { model } \\
\text { AA } \\
\text { GA+GG }\end{array}$ & $\begin{array}{c}9(6.0) \\
141(94.0)\end{array}$ & $\begin{array}{c}6(2.9) \\
198(97.1)\end{array}$ & 0.86 & $\begin{array}{c}2.1 \\
(0.73-6.05)\end{array}$ \\
\hline
\end{tabular}

* $\mathrm{p}<0.05$ : significant, OR: odds ratios, CI: confidence interval
Table (4) Comparison between group I (HCC patients) and non-HCC controls (group II \& III) regarding frequency of CYP6* alleles and genotypes and associated HCC risk

\begin{tabular}{|c|c|c|c|c|}
\hline Frequency & $\begin{array}{l}\text { Group I } \\
(\text { no }=150 \\
\text { No }(\%)\end{array}$ & $\begin{array}{l}\text { Controls } \\
(\text { no=204) } \\
\text { No }(\%)\end{array}$ & $\begin{array}{c}\text { p- } \\
\text { value }\end{array}$ & $\begin{array}{c}\text { OR } \\
(95 \% \mathrm{CI})\end{array}$ \\
\hline $\begin{array}{l}\text { CYP2D6*6 } \\
\text { Mut allele } \\
\text { Wt allele }\end{array}$ & $\begin{array}{c}233(77.7) \\
67(22.3)\end{array}$ & $\begin{array}{l}222(54.4) \\
186(45.6)\end{array}$ & $\begin{array}{c}<0.001 \\
*\end{array}$ & $\begin{array}{c}2.9 \\
(2.09-4.1)\end{array}$ \\
\hline $\begin{array}{c}\text { CYP2D6*6 } \\
\text { Dominant Model } \\
\text { Wt/Wt } \\
\text { Wt/Mut+Mut/M } \\
\text { ut }\end{array}$ & $\begin{array}{c}1(0.7) \\
149(99.3)\end{array}$ & $\begin{array}{c}31(15.2) \\
173(84.8)\end{array}$ & $\begin{array}{c}<0.001 \\
*\end{array}$ & $\begin{array}{c}0.037 \\
(0.002-0.2)\end{array}$ \\
\hline $\begin{array}{c}\text { CYP2D6*6 } \\
\text { Recessive Model } \\
\text { Mut/Mut } \\
\text { Wt/Mut+Wt/Wt }\end{array}$ & $\begin{array}{l}84(56.0) \\
66(44.0)\end{array}$ & $\begin{array}{c}49(24.0) \\
155(76.0)\end{array}$ & $\begin{array}{c}<0.001 \\
*\end{array}$ & $\begin{array}{c}4.0 \\
(2.5-6.4)\end{array}$ \\
\hline $\begin{array}{c}\text { CYP2D6*4 } \\
\text { A Mut allele } \\
\text { G Wt allele }\end{array}$ & $\begin{array}{c}46(15.3) \\
254(84.7)\end{array}$ & $\begin{array}{l}101(24.8) \\
307(75.2)\end{array}$ & $0.002 *$ & $\begin{array}{c}0.55 \\
(0.37-0.8)\end{array}$ \\
\hline $\begin{array}{c}\text { CYP2D6*4 } \\
\text { Dominant Model } \\
\text { GG } \\
\text { GA+AA }\end{array}$ & $\begin{array}{c}121(80.7) \\
29(19.3)\end{array}$ & $\begin{array}{l}131(64.2) \\
73(35.8)\end{array}$ & $0.003 *$ & $\begin{array}{c}2.3 \\
(1.42-3.85)\end{array}$ \\
\hline $\begin{array}{c}\text { CYP2D6*4 } \\
\text { Recessive Model } \\
\text { AA } \\
\text { GA+GG }\end{array}$ & $\begin{array}{c}17(11.3) \\
133(88.7)\end{array}$ & $\begin{array}{c}88(43.1) \\
116(56.9)\end{array}$ & $\begin{array}{c}<0.001 \\
*\end{array}$ & $\begin{array}{c}0.16 \\
(0.09-0.29)\end{array}$ \\
\hline $\begin{array}{l}\text { CYP2D6*3 } \\
\text { Mut allele } \\
\text { Wt allele }\end{array}$ & $\begin{array}{c}246(82.0) \\
54(18.0)\end{array}$ & $\begin{array}{l}255(62.5) \\
153(37.5)\end{array}$ & $\begin{array}{c}<0.001 \\
*\end{array}$ & $\begin{array}{c}2.73 \\
(1.9-3.9)\end{array}$ \\
\hline $\begin{array}{c}\text { CYP2D6*3 } \\
\text { Dominant Model } \\
\text { Wt/Wt } \\
\text { Wt/Mut+Mut/M } \\
\text { ut }\end{array}$ & $\begin{array}{c}3(2.0) \\
147(98.0)\end{array}$ & $\begin{array}{c}24(11.8) \\
180(88.2)\end{array}$ & $0.003 *$ & $\begin{array}{c}0.15 \\
(0.036- \\
0.47)\end{array}$ \\
\hline $\begin{array}{c}\text { CYP2D6*3 } \\
\text { Recessive Model } \\
\text { Mut/Mut } \\
\text { Wt/Mut+Wt/Wt }\end{array}$ & $\begin{array}{l}99(66.0) \\
51(34.0)\end{array}$ & $\begin{array}{c}75(36.8) \\
129(63.2)\end{array}$ & $\begin{array}{c}<0.001 \\
*\end{array}$ & $\begin{array}{c}3.32 \\
(2.1-5.2)\end{array}$ \\
\hline
\end{tabular}

* $\mathrm{p}<0.05$ : significant, OR: odds ratio, CI: confidence interval. 
Table (5) Model for prediction of HCC using logistic regression

\begin{tabular}{|c|ccc|}
\hline Genotypes & p-value & OR & 95\% CI \\
\hline $\begin{array}{c}\text { CYP2D6*3 } \\
\text { Mut/Mut }^{\text {a }}\end{array}$ & $<0.0001$ & 2.683 & $\mathbf{1 . 6 8 9 - 4 . 2 6 1}$ \\
\hline $\begin{array}{c}\text { CYP2D6*4 }_{\text {GG }^{\text {b }}} \\
\text { CYP2D6*6 }_{\text {Mut/Mut }^{\text {a }}}\end{array}$ & $<0.0001$ & 2.563 & $\mathbf{1 . 5 1 3 - 4 . 3 4 2}$ \\
\hline Constant & $<0.0001$ & 1.973 & $\mathbf{1 . 2 4 7 - 3 . 1 2 0}$ \\
\hline
\end{tabular}

${ }^{a}$ Mut/Mut (Mutant homozygous genotype) vs. Wt/Wt and $\mathrm{Wt} / \mathrm{Mut},{ }^{\mathbf{b}} \mathrm{GG}$ genotype (wild homozygous genotype) vs. GA and AA genotypes, *p-value <0.001: significant. OR: odds ratio, CI: confidence interval,

groups. Also, they were associated with increased risk of HCC compared to rapid acetylator alleles with OR and 95\%CI of 1.67 (1.21-2.3) and 1.99 (1.32-3.01) respectively. These results were consistent with those of Huang et al. (18) and Zhang et al. (19) who indicated that NAT2 genotypes were not associated with increased risk of HCC among the overall population but increased HCC risk among smokers. Meanwhile, Agundez et al. (20), and Khalaf et al. (21), found that NAT2 slow acetylators had an effect on HCC susceptibility and suggested that the NAT2 enzyme behaves as an inactivating enzyme of carcinogens and plays a protective role in averting the development of HCC. These results suggest that NAT2 gene may play different roles in hepatocarcinogenesis between HCC high and low prevalence areas, or among different ethnic groups.

In this study, NAT2 M1 and M2 rapid acetylators (CC and GG) showed significant decrease in HCC patients compared to $\mathrm{CHC}$ patients and to $\mathrm{CHC}$ patients and healthy subjects respectively. Moreover, there was a significant protective effect for rapid acetylators of NAT2 M1 (CC), M2 (GG) and M3 (GG) as they were associated with decreased HCC risk (dominant model, with OR of $0.06,0.54$ and 0.46 respectively). On the contrary, other authors have shown that rapid acetylators are at a higher risk of developing HCC (18) based on the hypothesis that the risk of cancer for rapid acetylators is due to the activation of procarcinogens such as heterocyclic amines.

This divergence over the role of NAT2 polymorphism in HCC may be explained by the fact that NAT2 is involved in different metabolic pathways of various aromatic amines (22). Also, exposure of different ethnic groups to different types of carcinogens varies from one region to another and the metabolism of carcinogens also involves a number of other enzymes (23).

Cytochrome P450 is a group of hepatic phase I drug metabolizing enzymes involved in the metabolism and elimination of most drugs in the human body (24).It is perhaps the most extensively studied polymorphic expressed drug metabolizing enzymes in humans and its polymorphism has a high clinical importance. There are four polymorphism-related phenotypes; poor (PM), intermediate (IM), extensive (EM), or ultra- rapid metabolizers (UM) (7).

The current study detected that the frequency of mutant alleles and genotypes (poor metabolizers) of CYP2D 6*6 and of CYP2D6*3 showed significant elevation in HCC group compared to controls, and were significantly associated with increased risk of HCC \{poor metabolizer (Mut/Mut) vs. intermediate (Wt/Mut) and extensive metabolizers (Wt/Wt); recessive model $\}$. These findings were in agreement with the study of Silvestri et al. (25). The authors 
reported that CYP2D6 genotypes have an effect on liver disease progression as shown by the distribution of different genotypes according to the severity of liver lesions.

Also, patients with intermediate metabolizers (IM) or poor metabolizers (PM) genotype that had less metabolic activity may not be able to respond to the treatment as with extensive metabolizers (EM) genotypes. Moreover, treatment with normal amount of drug dose in these patients will lead to its accumulation in the body and finally turns into carcinogen. Alternately, treatment of these patients with lower drug doses, will lead to drug resistance and poor outcomes (26). The current study showed significant elevation of IM genotypes of CYP2D6*6 and CYP2D6*3 in CHC patients compared to HCC patients suggesting their role in disease severity.

G to A (G1934A) transition (CYP2D6*4 allele) at the intron3/exon 4 boundary of the CYP2D6*4 gene leads to incorrect splicing of mRNA resulting in a frame shift and premature termination (27). This mutation result in decreased or lack of CYP2D6 isoenzyme activity, leading to poor metabolizer (PM) phenotype (28).

In the present study, the frequency of CYP2D6*4 extensive metabolizer $(\mathrm{G} / \mathrm{G})$ genotype was significantly increased in HCC group compared to the healthy subjects ( 80.75 vs, 57\%), and was significantly associated with increased risk of HCC with OR of 2.3, while A/A (poor metabolizer) genotype showed no significant difference between HCC patients and other groups, however it had a protection effect against HCC development as it was significantly associated with decreased HCC risk in the recessive model poor metabolizer (AA) vs. intermediate (GA) and extensive metabolizer
(GG) \} with OR of 0.16 . These observations were in consistence with other studies; Kimura et al. (29), Mochizuki et al. (30) and Sayed and Imam, (31).

Several studies have shown that the extensive metabolizer of CYP $2 * 4$ is associated with increased risk of several cancers (32), and reported that; the CYP2D6*4 may mediate the activation of procarcinogenic agents present in environment and the CYP2D6*4 gene might be in an association disequilibrium with the contributing genes.

UGT1A7 plays a critical role in the detoxification of carcinogens. Specifically, it was shown previously that polymorphisms in codons 129,131 , or 208 markedly decreased the carcinogen detoxification activity of UGT1A7 (33).

Our results demonstrated that no significant difference was detected between HCC, CHC patients and controls regarding the studied genotypes of UGT, also polymorphic pattern of UGT did not associate with susceptibility to HCC. These results agreed with study of Stücker et al. (34). On the contrary, Wang et al. (35) found that UGT1A7 alleles with lower activity were associated with HCC risk; UGT1A7 gene plays a critical role in the detoxification of hepatocarcinogens at the epithelia of the lung and gastrointestinal tract, which are thought to be entry sites for mutagens. Alternatively, there may be an unknown gene that is directly associated with HCC and that acts together with the UGT1A7 polymorphisms, or perhaps an unknown function of UGT1A7 affects the liver through actions at a different site. 


\section{Conclusion}

Increased risk for liver cancer in Egyptian patients infected with $\mathrm{HCV}$ may be associated with poor metabolizers of CYP2D $6 * 6$ and CYP2D $6 * 3$ and extensive metabolizer of CYP2D $6 * 4$. These genotypes could be a stratification marker in screening individuals at high risk of $\mathrm{HCC}$ in patients with chronic $\mathrm{HCV}$ infection

\section{Acknowledgement and Financial Disclosure}

The research was fully funded by a National Grant from Science and Technology development Fund (STDF), Egypt.

None of the contributing authors have any conflicts of interest.

\section{References}

1) WHO: International Agency for Research on Cancer: PRESS RELEASE $\mathrm{N}^{\circ}$ 224. Feb3; Lyon/London. Available from: URL:http://www.iarc.fr/en/mediacentre/pr/201 4/pdfs/pr224_E.pdf. Accessed December 5, 2015, 2014.

2) El-Garem H, Hafez HA, Foaud A, et al.: Tissue Biomarkers in the Early Detection of Hepatocellular Carcinoma among Egyptian Patients with Chronic Hepatitis C: A Possible Genetic Profile. Br J Med Res. 3:1858-1870, 2013.

3) Fontham ET, Thun MJ, Ward E, et al.: Cancer ACS and the Environment S. American Cancer Society perspectives on environmental factors and cancer. CA Cancer J Clin.; 59:343$351,2009$.
4) Francis GA, Fayard E, Picard F, Auwerx

J: Nuclear receptors and the control of metabolism. Annu Rev Physiol 65: 261-311, 2003.

5) Xu C, Li CY, Kong AN: Induction of phase I, II and III drug metabolism/transport by xenobiotics. Arch Pharm Res; 28:249-68, 2005.

6) Scordo MA, Caputi AP, D'Arrigo C, et al.: Allele and genotype frequencies of CYP2C9, CYP2C19 and CYP2D6 in an Italian population. Pharmacol. Res.; 50:195-200, 2004

7) Ingelman-Sundberg $\quad$ M.: $\quad$ Genetic polymorphisms of cytochrome P450 2D6 (CYP2D6): clinical consequences, evolutionary aspects and functional diversity. Pharmacogenomics J.; 5:6-13, 2005.

8) Hirvonen A.: Polymorphisms of xenobioticmetabolizing enzymes and susceptibility to cancer. Environ Health Perspect. ; 107 Suppl 1:37-47, 1999.

9) Agundez JAG, Olivera M, Ladero JM, et al.: Increased risk for Hepatocellular carcinoma in NAT2-slow acetylators and CYP2D6-rapid metabolizers. Pharmacogenetics; 6:501-12, 1996.

10) Fang JL, Beland FA, Doerge DR, et al.: Characterization of benzo $(\alpha)$ pyrene-trans-7,8dihydrodiol glucuronidation by human tissue microsomes and over-expressed UDPglucuronosyltransferase enzymes. Cancer Res; 62:1978-86, 2002. 
11) Bruix, J, and Sherman, M.: Management of hepatocellular carcinoma, Hepatology; 42 (5): 1208-1236, 2005.

12) Tsai J F, Chang W Y, Jeng J E, et al.: Hepatitis B and C virus infection as risk factors for liver cirrhosis and cirrhotic hepatocellular carcinoma: a case-control study, Liver; 14 (2): 98-9102, 1994.

13) Bell DA, Taylor JA, Butler MA, et al.: Genotype/phenotype discordance for human arylamine $\mathrm{N}$-acetyltransferase (NAT2) reveals a new slow-acetylator allele common in African- Americans. Carcinogenesis; 14:168992, 1993.

14) Tseng CS, Tang KS, Lo HW, et al.: UDPglucuronosyltransferase $1 \mathrm{~A} 7 \quad$ genetic polymorphisms are associated with hepatocellular carcinoma risk and onset age. Am J Gastroenterol, 100:1758-1763, 2005.

15) Zhou J, Wen Q, Li SF et al.: Significant change of cytochrome P450s activities in patients with hepatocellular carcinoma. Oncotarget. 2; 7 (31):50612-50623, 2016.

16) Farker K, Schotte U, Scheele J, Hoffmann A: Impact of $\mathrm{N}$-acetyltransferase polymorphism (NAT2 in hepatocellular carcinoma (HCC) - an investigation in a department of surgical medicine. Experimental and Toxicologic Pathology; 54 (5-6): 387-391, 2003.

17) Chang-Claude J, Kropp S, Jager B, et al.: Differential effect of NAT2 on the association between active and passive smoke exposure and breast cancer risk. Cancer Epidemiol Biomarkers Prev; 11: 698-704, 2002.

18) Huang YS1, Chern HD, Wu JC, et al.: Polymorphism of the $\mathrm{N}$ acetyltransferase 2 gene, red meat intake, and the susceptibility of hepatocellular carcinoma. Am J Gastroenterol. Jun; 98(6): 14117-22, 2003.

19) Zhang J, Feng Xu F, Ouyang C: Joint effect of polymorphism in the $\mathrm{N}$ acetyltransferase 2 gene and smoking on hepatocellular carcinoma. Tumor Biol.33:1059-1063, 2012.

20) Agundez JA, Ledesma MC, Benitez J, et al.: CYP2D6 genes and risk of liver cancer. Lancet; 345:830-1, 1995.

21) Khalaf F, Basuni A, El Daly M, et al.: Genetic polymorphism of $\mathrm{N}$ acetyltransferase 2 and its association with tumor markers and cigarette smoking in hepatocellular carcinoma. The Egyptian Journal of Biochemistry and Molecular Biology; 31(2): 119-142, 2012.

22) Gelatti U, Covolo L, Talamini R, et al.: N-Acetyltransferase-2, glutathione Stransferase M1 and T1genetic polymorphisms, cigarette smoking and hepatocellular carcinoma: a case-control study. Int J Cancer; 115: 301-6, 2005.

23) Zhang XF,Bian JH, Zhang HY et al.: Are polymorphisms of $\mathrm{N}$-acetyltransferase genes susceptible to primary liver cancer in Luoyang, China? World J Gastroenterol; 11(10):1457-1462, 2005. 
24) Rendic S.P. and Guengerich F.P: Survey of human oxidoreductases and cytochrome P450 enzymes involved in the metabolism of chemicals. Chem. Res. Toxicol. ; 28:38-42, 2015.

25) Silvestri L, Sonzogni L, De Silvestri A, et al.: CYP enzyme polymorphisms and susceptibility to HCV-related chronic liver disease and liver cancer. Int J Cancer; 104: 310-317, 2003.

26) Hussein S, Abd El-Aal1 A, Afify R, Noha El-Husseiny N: Study of the association of CYP2D6*4 polmorphism with the risk of chronic myeloid leukemia .Egypt J. Med. Lab. Sci.; 19 (2):71-78, 2010.

27) Surekha D, Sailaja K, Rao DN, et al.: Association of a CYP17 gene polymorphism with development of breast cancer in India. Asian Pac J Cancer Prev.; 11(6):1653-7, 2010.

28) Van Der Weide J and Steijns L.: Cytochrome P450 enzyme system: genetic pharmacology. Ann. Clin. Biochem. 36:722-9, 1999.

29) Kimura Y, Selmi C, Leung PS, et al.: Genetic polymorphisms influencing xenobiotic metabolism and transport in patients with primary biliary cirrhosis. Hepatology; 41(1):55-63, 2005.

30) Mochizuki J, Murakami S, Sanjo A, et al.: Genetic polymorphisms of cytochrome $\mathrm{P} 450$ in patients with hepatitis $\mathrm{C}$ virus- associated hepatocellular carcinoma. J Gastroenterol Hepatol. ; 20 (8):1191-1197, 2005.

31) Sayed S and Imam H: Study of the Association of CYP2D6*4 Polymorphism with the Susceptibility of HCV- Related Liver Cirrhosis and Liver Cancer. Life Science Journal; 9(3): 1571, 2012.

32) Raunio H, Husgafvel-Pursiainen $\mathbf{K}$, Anttila S, et al. : Diagnosis of polymorphisms in carcinogen-activating and inactivating enzymes and cancer susceptibility--A Review. Gene. 14; 159 (1):113-21, 1995.

33) Strassburg CP, Vogel A, Kneip S, et al.: Polymorphisms of the human UDPglucuronosyltransferase (UGT) $1 \mathrm{~A} 7$ gene in colorectal cancer. Gut; 50:851-6, 2002.

34) Stücker I, Loriot MA, N'koutchou G et al.: $\quad$ UDPglucuronosyltransferase UGT1A7 geneticpoly morphisms in hepatocellular carcinoma: a differential impact according to seropositivity of HBV or HCV markers? BMC cancer.Nv 19; 7:214, 2007.

35) Wang Y, Kato N, Hoshida Y, et al.: UDP-glucuronosyltransferase 1A7 genetic polymorphisms are associated with hepatocellular carcinoma in Japanese patients with hepatitis $\mathrm{C}$ virus infection. Clin Cancer Res; 10:2441-6, 2004. 